\title{
Викопні водорості
}

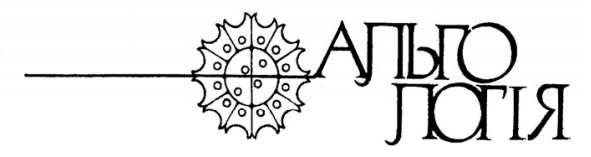

ISSN 0868-854 (Print); ISSN 2413-5984 (Online).

Algologia. 2021. 31(2): 141-149

https://doi.org/10.15407/alg31.02.141

\section{Комплекси діатомей верхнього пліоцену та їхнс значення для встановлення нижньої межі квартеру (південь Далекого Сходу)}

\section{Пушкар В.C.}

Далекосхідний геологічний інститут ДСВ РАН, Росія,

пр. 100 років Владивостоку, 159, Владивосток 690022, Росія

vlpushkar@mail.ru

Надійшла до редакціi 20.04.2021. Після доопрацювання 12.05. 2021. Підписана до друку 21.05.2021.

Опублікована 29.06.2021

Реферат. Рішенням Міжнародного союзу геологічних наук (Норвегія, 2009 р.), прийнятим за поданням Міжнародної комісії з стратиграфії, запропоновано встановити нижню межу квартеру на рівні 2,58 млн років. Таке рішення викликало бурхливу дискусію, яка вимагає серйозного обгрунтування нового положення стратиграфічної межі і включення гелазького ярусу пліоцену до складу квартеру, що може значно вплинути на розробку структури та ієрархії стратиграфічних підрозділів квартеру. Особливо гостро дискутується питання про критерії проведення нової межі, іiї уніфікації у різних географічних регіонах і регіональних геологічних стратотипах. Розглядається питання про критерії і правомірність проведення нової неоген-четвертинної межі у верхньокайнозойських континентальних відкладах Примор'я за діатомеями.

К л ю ч о в і с л о в а : квартер, пліоцен, гелазький ярус, шуфанський горизонт, палеоклімат, Примор'я

Вступ

Сьогодні особлива увага геологів, які займаються вивченням четвертинних відкладів, приділяється проблемі обгрунтування і критеріїв проведення нижньої межі квартеру на рівні 2,58 млн років i, отже, включення гелазького ярусу до структури його підрозділів. Це рішення, за поданням Міжнародної комісії з стратиграфії (ICS), було прийнято Міжнародним союзом геологічних наук (IUGS) в 2009 р., чому передувало бурхливе обговорення цієї проблеми на 33-му Міжнародному геологічному конгресі

(C) Пушкар B.C., 2021 
(Осло, Норвегія, 2008 р.). Стратотип нижньої межі Гелазія - розріз Монте Сан Нікола (Сицилія) затверджено у 1996 р. На цьому рівні розташовується межа між палеомагнітними ортозонами Матуяма-Гаусс і започаткуванням 103-ї киснево-ізотопної стадії (Ogg, Pillans, 2008; Pillans, Gibbard, 2012).

У Росії проблема нижньої межі квартеру також бурхливо обговорювалася навесні 2011 р. За рекомендацією неогенової і четвертинної комісій Міжвідомчого стратиграфічного комітету (МСК) спільно з Комісією по вивченню четвертинного періоду РАН, межа між неогеном і квартером була прийнята на рівні 2,58 млн років (Modern..., 2011). Таке рішення має дуже серйозні наслідки, оскільки пов'язане 3 проведенням геологічної великомасштабної зйомки i складанням нових регіональних карт четвертинних відкладів для пошукової геології. При виділенні самих критеріїв проведення межі регіональних підрозділів квартеру слід врахувати зауваження О.А. Світоча (2016) щодо співвідношення обсягів і положення меж ярусів Міжнародної стратиграфічної шкали (МСШ) і підрозділів регіональних шкал. На прикладі Великого Каспію (ВК) він показав, що нижні межі ярусів МСШ і регіоярусу ВК, як і палеогеографічні ситуації, співвідносяться по-різному. Основними причинами таких невідповідностей можуть бути різновимірність, відмінності і ієрархія подій порівнюваних об'єктів - Світового океану і Каспійського регіону. Важливо враховувати також різні критерії виділення ярусів в МСШ і регіоярусу ВК. При міжрегіональній кореляції стратиграфічних підрозділів, зокрема гелазького ярусу, завжди існуватимуть ускладнення, обумовлені різним ступенем комплексної вивченості, а в континентальних товщах - i фаціальною різнорідністю. Мабуть, такі ускладнення універсальні для будь-яких регіонів.

В офіційно прийнятій і затвердженій Регіональній стратиграфічній схемі палеогенових і неогенових відкладів півдня материкової частини Далекого Сходу (Decisions..., 1994) пліоценові відклади були включені до стратиграфічного об'єму суйфунського горизонту (суйфунська свита). Вважалося, що відклади суйфунської свити латерально заміщуються відкладами шуфанської свити 3 найбільш повними розрізами в районі Шуфанського плато. Пізніше стратиграфічний об'єм суйфунського горизонту був переглянутий і доведена його відповідність еоплейстоцену, тому шуфанський горизонт не може бути латеральним фаціальним аналогом суйфунському (Pavliutkin, Petrenko, 2010).

Власне шуфанська свита в стратотипічному розрізі (скв. 415, рис. 1) складена в нижній i верхній частинах потоками андезитобазальтів потужністю 25 і 13 м відповідно та міжбазальтовими глинами і пісками 3 прошарками туфодіатомітів (потужність 48 м), що утворилися в озерних умовах. Шуфанські відклади мають досить серйозне мікропалеонтологічне обгрунтування і радіометричні датування, що вказують на 
їхню приналежність до пліоцену (Kovalenko, 1989; Pavliutkin, Petrenko, 2010), що унеможливлює їх перенесення на еоплейстоценовий рівень. Такі часові протиріччя призвели до перегляду статусу шуфанської свити як фаціального аналога суйфунської свити і стала підставою для виділення однойменного регіонального шуфанського горизонту в стратиграфічній схемі неогену Примор'я (Pavliutkin, Petrenko, 2010). Перекривають відклади шуфанського горизонту червоноколірні товщі анненського горизонту, запропонованого Б.І. Павлюткіним і асоційованого ним зі гелазьким ярусом (Pavliutkin, Petrenko, 2010). Вище анненського горизонту залягають відклади суйфунської свити, добре охарактеризовані мікропалеонтологічними даними (карпологічний, спорово-пилковий і діатомовий аналізи), що відповідають еоплейстоценовому рівню. Палеомагнітні дослідження показали, що верхня частина відкладів анненського горизонту характеризується переважно зворотною залишковою намагніченістю. Це дає підставу розглядати можливий час іiі накопичення в одному з епізодів всередині ортозони Гаусс або в ранній період ортозони Матуяма (Pavliutkin, Petrenko, 2010).

\section{Матеріали та методи}

Найбільш повний розріз пліоцену (гаданий стратотип - розріз 4131) розташований в околицях с. Терехівка поблизу місця буріння скв. 415 (Пушкінська западина, координати: $43^{\circ} 20$ '25' 'п.ш. та $131^{\circ} 52^{\prime} 59$ " с.д.) i нарощує розріз 4130 усть-суйфунської свити (рис. 1). Ці ж шари пліоцену прослідковуються в рівнях 4128 та 4129 біля західної околиці с. Червоний Яр (координати: $43^{\circ} 41$ '40' 'п.ш. та $131^{\circ} 54^{\prime} 54$ " с.д.).

Осадова товща розрізу 4131 відома як кедрівська товща (Denisov, 1960). Саме цей розріз і пропонується вважати стратотипом горизонту, оскільки він досить повно охарактеризований викопною листовою флорою, даними спорово-пилкового і діатомового аналізів (Pavliutkin, Petrenko, 2010; Pushkar et al., 2019).

Відклади розрізу 4131 представлені знизу догори:

1. Глина щільна, синювато-сіра, в окремих прошарках алевриста 5,6 м

2. Піски світло-сірі, дрібнозернисті, хорошого сортування $0,65 \mathrm{M}$

3. Глина щільна, синювато-сіра, в окремих прошарках алевриста $0,25 \mathrm{M}$

4. Алевроліт світло-сірий, у верхній частині зі слідами грунту $0,55 \mathrm{M}$

5. Піски світло-сірі, дрібнозернисті, хорошого сортування, у верхній частині алевристі $3,8 \mathrm{M}$

6. Похований грунт з гумусовим й ілювіальним горизонтами 0,5 м Загальна потужність $11,05 \mathrm{M}$ 


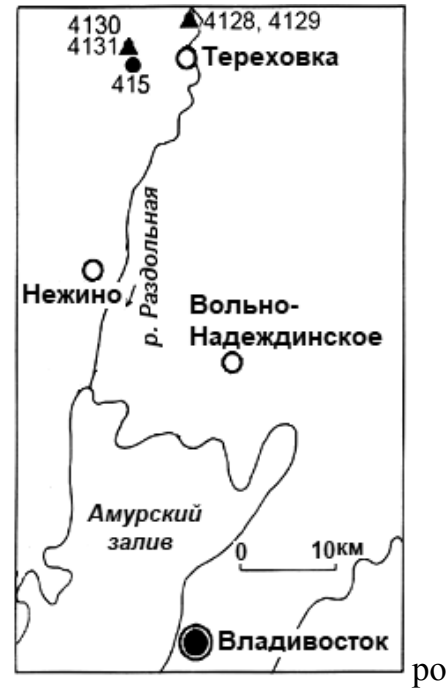

Рис. 1. Схема розташування досліджених розрізів пліоцену Примор'я

Перекриваються відклади базальтовим покривом потужністю 0,7 м та алевролітами потужністю 1,1 м. Базальти верхнього потоку мають зворотню залишкову намагніченість, яка відповідає палеомагнітній ортозоні Matuyama (Alekseev, 1978).

\section{Результати та обговорення}

Виділені у відкладах шуфанської свити комплекси діатомей належать діатомовим зонам Alveolophora tscheremissinovae та Aulacoseira praegranulata var. praeislandica f. praeislandica (рис. 2). На межі міоценпліоцен також відзначено першу еволюційну появу A. subarctica (Müller) Haworth, Pliocaenicus costatus (Loginova, Lupikina et Khursevich) Flower, Ozornina et Kuzmina, Stephanodiscus grandis Khursevich et Loginova, S. hantzschii Grun. i S. nativus Lupikina, Khursevich, Ozornina. Хорошим маркером пліоцену відкладень служить масове трапляння Alveolophora tscheremissinovae Khursevich

Комплекс зони A. tscheremissinovae (нижній пліоцен, шари 1-3). Верхня межа зони проводиться по вимиранню виду-індексу. Вік 5,33,6 млн років. Комплекс діатомей характеризується A. tscheremissinovae, A. praegranulata var. praeislandica f. praeislandica (Jousé) Moiss., Melosira undulata (Ehr.) Kütz., Ellerbeckia arenaria f. teres (Brun) Crawford, Fragilariforma bicapitata (A.Mayer) Williams et Round, Cymbella tumida (Bréb.) Van Heurck i Sellaphora americana (Ehr.) Mann, Cymbella australica (A.S.) Cl. Вимерлих видів близько 10\%. Спостерігається вище видове різноманіття, ніж у попередньому комплексі, а також участь теплолюбних видів, що відповідає незначному потеплінню клімату початку пліоцену. 


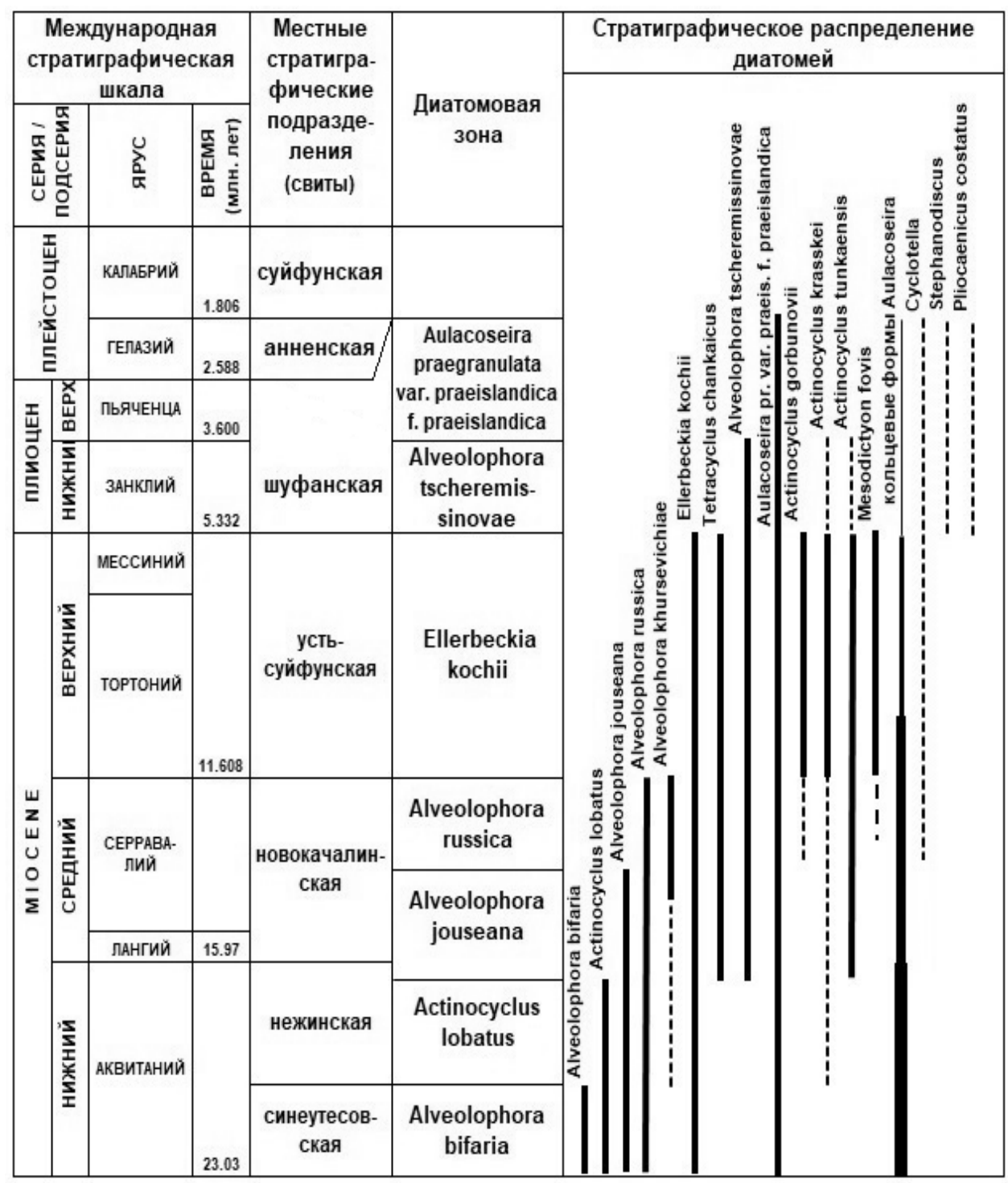

Рис. 2. Зональна діатомова шкала неогенових відкладів Примор'я (Pushkaret al., 2019) з незначними уточненнями

Комплекс зони Aulacoseira praegranulata var. praeislandica $\mathrm{f}$. praeislandica (верхній пліоцен, шари 4-6). Верхня межа відповідає рівню вимирання виду-індексу. Вік 3,6-2,58 млн років. Віковий комплекс, що відображає еволюційний етап у розвитку діатомей, представлений A. praegranulata var. praeislandica f. praeislandica (Jousé) Moiss., A. distans (Ehr.) Simonsen, A. praegranulata var. praegranulata (Jousé) Moiss., A. italica (Kütz.) Simonsen, Melosira undulata var. undulata (Ehr.) Kütz., 
Ellerbeckia arenaria f. teres (Brun) Crawford, Eunotia clevei Grun., Tetracyclus ellipticus var. lancea (Ehr.) Hust. Вимерлих видів, крім грубопанцирних різновидів Aulacoseira praegranulata (Jousé) Simonsen, немає. У відкладах суйфунської свити вже також немає грубо-панцирних Aulacoseira, що зближує цю флору із сучасною (Pavliutkin, Petrenko, 2010). Значно знижене видове різноманіття діатомей, відсутній помірно тепловодний елемент флори. Бентичні діатомеї превалюють (до 78\%), що свідчить про посилення алювіального седиментогенеза порівняно 3 лімнічним. Комплекс відображає нову хвилю похолодання і стабілізацію холодних умов.

В екологічному відношенні два наведені вище комплекси відрізняються. Нижній комплекс характерний для озерних глибоководних фацій, засвідчить про домінування бентичної Melosira undulata var. undulata, яка мешкає переважно в глибоких озерних біотопах, а також наявність представників планктонних родів Ellerbeckia R.M.Crawford, Cyclotella Kützing) Brébisson, Pliocaenicus Round \& Håkansson i Stephanodiscus Ehrenberg. Присутність у комплексі тепловодних діатомей Actinella brasiliensis Grun., Cymbella tumida (Bréb.) Van Heurck i Sellaphora americana (Ehr.) Mann (до 41,3\%) свідчить про відносно теплий клімат раннього пліоцену, що також підтверджують інші автори (Pavliutkin, Petrenko, 2010).

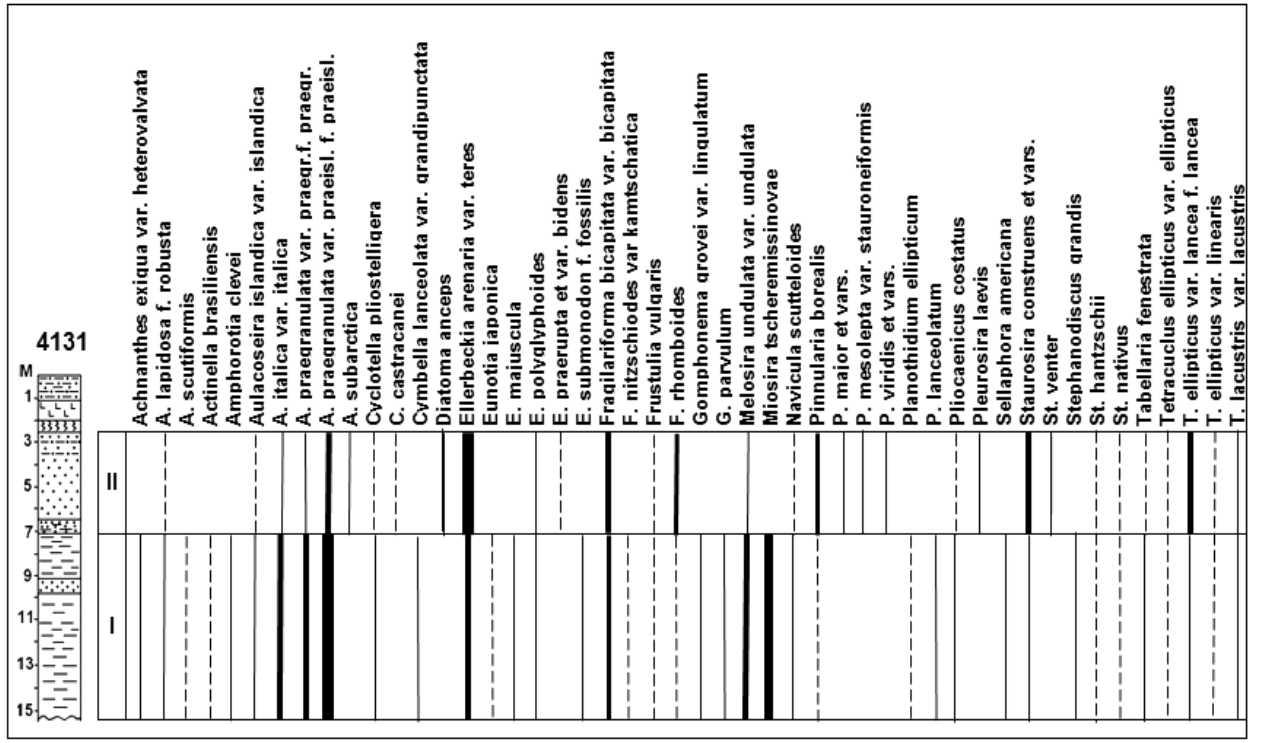

Рис. 3. Діатомова діаграма відкладів опорного розрізу пліоценових відкладів (розріз 4131, літологічний опис шарів див. в тексті) 
Для верхнього комплексу характерне домінування більш мілководних представників роду Aulacoseira і відсутність тепловодних діатомей, що свідчить про зниження рівня води в озері і початок сильного глобального похолодання в пізньому пліоцені 3 максимальною фазою 2,58 млн років. В мусонній циркуляції домінує зимовий мусон. 3 цього моменту починається співіснування і експансія полярних льодовикових шапок (перехід планети 3 режиму "Green house" в режим "Ice house"), які визначили формування сучасної кліматичної системи Землі (Wang et al., 2003).

Аналогами описаних комплексів є діатомеї відкладів розрізу 4129, розташованого на західній околиці с. Червоний Яр (див. рис. 1), який нарощує без слідів перерви розріз 4128 (усть-суйфунська свита).

Дані діатомового аналізу цілком відповідають даним споровопилкового аналізу (Pavliutkin, Petrenko, 2010). В осадової товщі розрізу 4131 виділяються два спорово-пилкових комплекси.

Спорово-пилкові спектри нижньої частини розрізу (шари 1-3) характеризуються переважанням пилку покритонасінних над голонасінними. Серед покритонасінних помітну роль відіграє пилок широколистяних порід: Castanea (до 4,3\%), Carpinus (до 6\%), Corylus (до 3,6\%), Juglans (до 5,1\%), Ulmus (до 4,3\%). Серед голонасінних домінує Pinus subg. Haploxylon (4-19,2\%). Значно менше Picea sect. Omorica (1,4-2,3\%) і представників Taxodiaceae (1,2-2,3\%). Серед дрібнолистяних багато Betula (2,9\%) та Alnus (до 19,3\%).

Для верхнього комплексу (шари 4-6) характерна відсутність пилку широколистяних порід. Зустрічаються лише поодинокі пилкові зерна Juglans, Carpinus, Corylus, Quercus, Fagus, Ulmus, Acer, Tilia, Syringa, що робить спектр близьким до еоплейстоценових. Це дає підставу припускати, що осади у верхній частині були сформовані в епоху глобального похолодання в інтервалі 2,2-3,0 млн років 3 максимальною фазою, яка не поступається масштабністю останньому оледенінню планети на рівні 2,4-2,5 млн років (Pavliutkin, Petrenko, 2010).

Такі для пізнього кайнозою спектри відображають пліоценові коливання клімату, добре виражені на глобальних палеотемпературних кривих (Wang et al., 2003; Pavliutkin, Petrenko, 2010).

\section{Висновки}

Аналіз поширення діатомей у розрізах пізнього кайнозою показує, що до рівня анненського горизонту (гелазький ярус) практично повністю зникають вимерлі види. Для відкладів діатомової зони Aulacoseira praegranulata var. praeislandica f. praeislandica чітко зазначається превалювання алювіального типу седиментогенезу і скорочення площі озерних басейнів. Похолодання пізнього пліоцену з вираженим темпе- 
ратурним мінімумом на рівні близько 2,58 млн років досить яскраво відображено в екологічних структурах діатомових асоціацій (верхній комплекс) - переважають бентична аркто- і північно-бореальна флори. Для цього часу характерна також повна відсутність пилку широколистяних порід, а палеоландшафти стають близькими до еоплейстоценових. С цього моменту починається співіснування і експансія полярних льодовикових шапок (перехід планети з режиму "Green house" в режим "Ice house"), які визначили формування сучасної кліматичної системи Землі, що підкреслює глобальність палеокліматичної події. У літологічному плані для південної частини Примор'я з цією межею збігається підошва товщі красноцвітів анненського горизонту, яка відповідає підошві гелазького ярусу $(2,58$ млн років). Вікове зниження межі квартера до цього стратиграфічного рівня носить цілком обгрунтований характер.

\section{Список літератури}

Alekseev M.N. 1978. Anthropogene of the Eat Asia. Moscow: Nauka. 2008. 108 р. [Алексеев M.Н. 1978. Антропоген Восточной Азии. М.: Наука. 208 с.]

Decisions of the $4^{\text {th }}$ Interdepartmental Stratigraphic Meeting on Precambrian and the Phanerozoic of the South of the Far East and Eastern Transbaikalia. 1994. Khabarovsk. 124 p. [Решения 4-го Межведомственного стратиграфического совещания по докембрию и фанерозою юга Дальнего Востока и Восточного Забайкалья. 1994. Ред. М.Т. Турбин. Хабаровск. 124 c.].

Denisov E.P. 1960. To the question of the stratigraphy of the Upper Cenozoic formations of the Southwestern Primorye. Rep. Far Eastern Branch Sib. Branch USSR Acad. Sci. 12: 19-23. [Денисов Е.П. 1960. К вопросу о стратиграфии верхнекайнозойских образований ЮгоЗападного Приморья. Сообщ. ДВФ СО АН СССР. 12: 19-23].

Kovalenko S.V. 1989. In: The Cenozoic of the Far East. Vladivostok: FEB RAS. Pp. 64-72. [Коваленко С.В. 1989. В кн.: Кайнозой Дальнего Востока. Владивосток: ДВО АН CCCP. C. 64-72].

Modern problems of the Neogene and Quaternary stratigraphy of Russia. 2011. Ed. Yu.B. Gladenkov. Moscow: GEOS. 108 p. [Современные проблемы стратиграфии неогена и квартера России. 2011. Ред. Ю.Б. Гладенков. М.: ГЕОС. 108 с.].

Ogg J., Pillans B. 2008. Establishing quaternary as a formal international period / System. Episodes. 31(2): 230-233. doi:10.18814/epiiugs/2008/v31i2/008

Pavliutkin B.I., Petrenko T.I. 2010. Stratigraphy of Paleogene-Neogene deposits of the Primorye. Vladivostok: Dalnauka Press. 164 p. [Павлюткин Б.И., Петренко Т.И. 2010. Стратиграфия палеоген-неогеновых отложений Приморья. Владивосток: Дальнаука. $164 \mathrm{c.}$ ]

Pillans B., Gibbard P. 2012. In: The geological time scale. Amsterdam: Elsevier. Pp. 979-1010. doi: 10.1127/0078-0421/2012/0020 
Pushkar V.S., Likhacheva O.Yu., Usoltseva M.V. 2019. Zonal Diatom Scale of the Continental Neogene in Primorye (Most Southern Territory of the Russian Far East). Int. J. Algae. 22(3): 163-176. https://doi.org/10.1615/InterJAlgae.v21.i2.60

Svitoch A.A. 2016. Position of lower boundaries of the international stratigraphic scale stages of upper Pliocene and Quaternary in succession of Great Caspian Sea and paleogeographical events. Bull. Mosc. Soc. Nat. 91(2-3): 63-73. [Свиточ А.А. 2016. Положение в разрезах Большого Каспия нижних границ ярусов верхнего плиоцена и квартера Международной стратиграфической шкалы и палеогеографические события. Бюл. Моск. общ-ва испыт. природы. 91(2-3): 63-73].

Wang Pinxian, Zhao Quanhong, Jian Zhimin, Cheng Xinrong, Huang Wei, Tian Jun, Wang Jiliang, Li Qianyu, Li Baohua, Su Xin. 2003. Thirty million year deep-sea records in the South China Sea. Chin. Sci. Bull. 48(23): 2524-2535.

Підписала до друку О.П. Ольштинська

Pushkar V.S. 2021. Upper pliocene diatom complexes and its significfnce to establish lower boundary of quarter (South of the Far East). Algologia. 31(2): 141-149

Far East Geological Institute of the Far East Branch of the Russian Academy of Science, 159 100-Letiya Ave., Vladivostok 690022, Russia

An analysis of the evolutionary distribution of diatoms in the outcrops of the Late Cenozoic shows that, upon reaching the level of the Annensky Horizon (Gelazian stage), the extinct species disappear almost completely. A predominance of the alluvial type of sedimentogenesis and reduction in the lake basins areas are clearly registered for deposits of the diatom zone Aulacoseira praegranulata var. praeislandica f. praeislandica. A cooling in the Late Pliocene with the pronounced temperature minimum at the level about 2,58 million years is fairly bright reflected in the ecological structures of diatomic associations (upper complex): the benthic arcto- and northboreal flora predominates. Of that time, a total absence of the pollen of the broad-leaved species is also characteristic and paleo-landscapes become close to the Eopleistocene ones. From this moment on, the coexistence and expansion of the polar ice sheets begin (transition of planet from the "Green house" mode to the "Ice house" mode) which determine the formation of the modern climatic system of the Earth which emphasizes the globality of the palaeoclimatic event. From the lithological point of view, the bottom of the red rocks strata of the Annensky Horizon corresponding to the Gelazian stage bottom (2,58 million years) coincides with this boundary in the southern Primorye. The age changes of the Quarter boundary to this chronostratigrahic level is well founded.

K e y w o r d s : Quarter, Pliocene, Gelazian stage, Shufansky horizon, paleoclimate, Primorye 